\title{
MFIs Commercialization New Opportunity to Sustainable Profit
}

\author{
Prof.As. Dr. Remzi Sulo ${ }^{1}$ \\ Prof.As. Dr. Etleva Muça (Dashi)² \\ Prof.As. Dr. Ana Kapaj2 \\ ${ }^{1}$ Faculty of Applied and Economics Sciences, Albanian University \\ ${ }^{2}$ Faculty of Economy and Agribussines, Agriculture University of Tirana
}

\section{Doi:10.5901/ajis.2016.v5n3s1p451}

\begin{abstract}
Microloan determines the methods, that create opportunities to offer micro loans to very poor families in order to help them realize their productive activities and offer them the possibility to develop small businesses. Microfinance is not limited to offer small loans to the poor, but also a wide range of financial services to all of which are excluded from the classic financial system. The Albanian financial sector is not only dominated from the commercial banks, but also from a high number of non commercial financial institutions (16 commercial banks, 27 noncommercial banks, 1 representative of foreign banks, 397 exchange offices, 111 credit union associations and 2 credit union association.) (Bank of Albania, 2015). Microfinance institutions cover especially rural and sub urban areas focusing their services in areas, where financial services lack. Particularly in rural areas is proven that these financial institutions have helped farmers to overcome the emergency phase and, subsequently, have spurred development, creating some of the first financial structures in rural areas, as well as enabling villages to manage loans and other development projects. (Salko D., 2000). The article purpose is related to the future of the microfinance system in the country as a necessity for them to have more consolidated structure in terms of legal framework (transforming them into commercial banks) and the possibility to offer lower interest rate for the offered services. If the first structure is linked to the core changes of these institutions and the second is offering a strategy for market adjustment strategy.
\end{abstract}

Keywords: MFI commercialization, micro loan, financial sector, microfinance system.

\section{Introduction}

In its early start microfinance was formed voluntarily to help the people in need. Although nowadays it represents a market solution for poverty reduction.

Actually as never before the world is paying attention the link among finance and poverty and the idea of past decade of low income people who represent a new business segment which is becoming more attractive. (Daryl Collins. 2009).

To predict how the future of microfinance will be, we have to understand a wider range of services well perceived from the market where it operates. Deeper the financial markets, the greater are the benefits from the financial intermediary.

According the Jean Philippe de Screvel: "Commercialization is not a goal itself, but ensures effective products and financial services". In reality it suggests that microfinance can be a profitable business with effective interest rates at market level and the loan re payment to be at $97 \%$ rate, which is much higher than the commercial banks.

At this level we raise the questions below:

1. Which is the actual status of the microfinance institutions that operate in Albania?

2. What is the condition of the financial sector and what is the microfinance long term strategy?

Given the research questions and issues, we raise the following hypothesis:

Ho: The commercialism of the microfinance institutions will bring positive effects in the Albania financial market

Microfinance institutions are being efficient as financial intermediaries, because with their managerial and professional capabilities have restored a nonexistent financial market, lending in regions excluded from the traditional banking system.

Although Microfinance Institutions play a major role they have a disadvantage in terms of higher capital costs. They should seek to reduce the overall lending costs to balance the high operations costs caused by small amounts of loans. 
This means that a microfinance institution has much more operational expenditures on staff, logistics etc.

\section{Methodology}

Our work will be realized through factorial analysis, because we will start from the phenomena and real microfinance cases in Albania and worldwide to explain the phenomena in general, which is linked to the transformation into long term and sustainable institutions with commercialized profile.

A very important part of the information will be used from the Bank of Albania data base. This institution ensures a transparent and credible source of information related to MFIs their financial sources and the way they operate. Bank of Albania makes a descriptive statistical analysis for the stability of micro financial markets.

Public data give detailed information for the average number of loans, number of active borrowers, non performing loans, and financial rapports. The information is elaborated through computer programs, such as Microsoft excel, where some Pivot Tables are made through the Bank of Albania data.

\section{Results}

The information provided from the microfinance institutions is very formal regarding the regulative side, but not the developing strategies. This gap is generated from the Bank of Albania, because these are the data requested by it.

This vigilance of the Bank of Albania justifies the share of microfinance institutions in the banking sector. Some publications are made only by specialists of the Bank of Albania, which have been more descriptive than analytical (Nako A. etc. Buletin the Bank of Albania,2011).

Compared with the other countries within the region, it is noticed exist spaces for a more active role of the financial intermediaries related to the development of microfinance. The highest level of the average loan compared the gross national income per capita compared to the countries within the region (excluding Kosovo), shows that within the population with low income the penetration of microfinance results insufficient.

The changes of the microfinance regulatory framework has enabled new licensed operators, under the new requirements to be oriented at this segment of borrowers, which represent the main objective of microfinance. Currently the supply of microfinance is oriented mainly into the urban areas of the country leaving uncovered the rural areas with financial services. Depending on the type of the institution and its level of development, there are different levels of customer target groups and different type of loans, which are materialized in the level of the development of the average loan. (Nako A. etc. 2011)

At the end of year 2014, the Albanian microfinance market outside the banking sector results with a gross loan portfolio of 32,230 million Albanian ALL, equivalent to 23.19 million EUR. The performance of this portfolio tends to increase, but at reduced rates during 2012-2013. Under these conditions the number of the active borrowers is increasing from a year to another, but there is a decrease in the average loan portfolio as a reduction in the loan outstanding for new borrowers, mainly during year 2013. This represents one of the measures in response to the financial development in the country.

The level of nonperforming loans appears to have slightly increased, excluding year 2010, where there was a significant deterioration. Microfinance market development analyzes the non banking financial institutions and the SCAs network. Relevant indicators of the banking sector are not included, given the different characteristics of the banking activities regarding the nature of the customers, the maximum credit amount and specifics of the regulatory and supervisory framework.

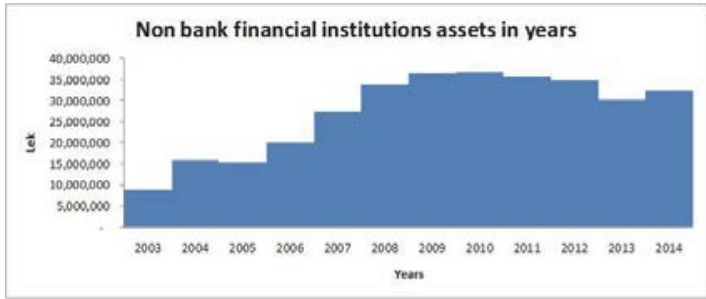

Graph 1. Weighted assets on non banking institutions (million Albanian ALL)

Source: Bank of Albania, 2015 
The active clients have the same increasing trend as the loan portfolio. The highest loan portfolio and number of clients have been in year 2009. The main causes of a not higher portfolio and number of clients are as a consequence of:

- World financial crises of year 2007 involved Albania too. In our country the crises showed its effects in 2009, due to the increase of nonperforming loans (Bank of Albania 2010)

- Reduction of remittances. According the reports of the Bank of Albania in 2007 remittances were 952 million EUR, a figure that fell sharply in 2010 to 690 million EUR, while in 2012 remittances fell to 675 million EUR.

Loan portfolio represents $56.3 \%$ of the total assets in the structure of the non banking financial institutions. The rest of the total assets is oriented by cash in hand, deposits and current accounts (22.6\%), and treasury bills with different face value (11.8\%).

Non banking financial institutions are mainly financed by the loans borrowed (54.6\%) and their own capital (37.7\%). The loans borrowed are mainly from the domestic banks (40.2\% of the loans borrowed) and non resident financial institutions (37.4\%) meanwhile there are other sources of financing from other local sources. The major part of the non bank financial institutions' loan portfolio is made by institutions on giving loans, followed by leasing institutions with $37,0 \%$ and the rest portfolio by factoring institutions.

During 2014 the gross loan portfolio of non banking financial institutions had a slight increase of 51.6 million ALL (0.4 million EUR) a total amount of 19.73 billion ALL (142 million EUR) or which represents $3.32 \%$ of the total portfolio of the banking sector. Gross portfolio growth is mainly attributed to the activity of lending and microcredit entities (1.64\%), as well as factoring entities. (149\%). Meanwhile in 2014 the financial leasing continues to decrease (3.94\%).

The nonperforming loans (gross) has increased during 2014 with approximately 115.32 million ALL (0.8 million EUR). This growth has led to the deterioration of the nonperforming loan indicators for SFJB. In December 2014, the indicator appears to be $13.74 \%$. The financial leasing portfolio has influenced the nonperforming loans increase of SFJB with approximately 327.22 million ALL (2.35 million EUR) or 32.8\% Meanwhile, microcredit loan portfolio has a decrease of nonperforming loans, with an amount of 212.4 million (1.5 million euro) (13.7\%) compared with 2013 and 2014, amounted to $11.82 \%$.

In the yield evaluation of non banking financial institutions and ASCs there are differences for the same micro market. This difference is explained with lower capital costs that they use and the high costs that Micro Finance Institutions need the achieve the necessary profitability.

During 2014 the non banking financial institutions have generated the positive income of 754.5 million Albanian ALL (5,4 million EUR). This result has shrunk with approximately 396 million Albanian ALL (2.8 million EUR) (or 35\% compared to the previous year).

In the majority of the non banking financial institutions we notice a weak performance. The profits of non banking financial institutions makes approximately $6.7 \%$ of the result of the overall banking system.

\section{The Regulative Framework and the Bank of Albania Role in Development and Regulation of the Microloan}

The current legislation in Albania for microfinance has been framed in a way that allows this institutions (except for saving and credit unions) to allow them in lending if they have the licences as non banking financial institutions. The legal framework is based on the law "For banks in the Albanian Republic" meanwhile the Law "On Savings and Credit Associations" regulates the activity of savings and loan associations and their unions.

The focus of the Bank of Albania has been oriented toward adopting and developing a legal framework, either to allow sufficient monitoring of microfinance/ microcredit activity or to give a positive an extra incentive to its development.

In February 2009 the new licensing regulation for non banking institutions has defined this activity, excluding it from other activities and enabling easier requirements for initial capital.

This innovation provided in this regulation has enabled the growth of licensing requests for non-bank financial entities, which provide microcredit. During 2015, within the scope of the licensing function, the Bank of Albania has licensed six non banking financial entities, three microcredit financial institutions such as (Micro Credit Albania Ltd, lutecredit Albania JSC, Agro Partner Itd) two electronic money institutions (Vodafone M-PESA Itd, Easypay Itd), a nonbanking financial entity to exercise financial activities factoring and financial leasing (Crimson Finance Fund Albania Itd), as well as license revocation of the non banking institution such as EasyPay Ltd due to its transformation in electronic money institution.

The supervising process has undergone positive developments toward strengthening the supervision and analytical structures. Supervising these institutions even when they do not accept deposits is important, because the Bank of Albania improves their operational management, increasing their reporting standards and healthy loan practices. 
This enables more funds thus creating more spaces for business expanding, more customers and a wider range of products offered and the creation of financial independence.

Supervision of these entities including Saving and Credit Associations are based on the licensing criteria and supervision norms that should be respected. The main aspects of the supervising regulatory framework have to deal with capital adequacy, credit risk, liquidity and foreign currency position. One of the main risk is the loan risk.

Expectation of the portfolio quality indicators are increasing. This mainly affected from the supply side toward the decrease of the loan portfolio in two main aspects:

Referred to the microcredit loan portfolio structure, divided by the economic sectors at the end of 2014, diversification is and should be considered and a long term support of the Albanian economy, such as tourism and agriculture.

It continues to be dominated in business financing (92.3\%),, oriented toward services and trade sectors. "Trade, vehicle repairmen and domestic appliances" (29.3\%); "Agriculture, hunting and silviculture" (12.9\%); and "other " $(11.9 \%)$.

This lending orientation is judged positively in cases when the above sectors represent an important contribution to the per capita growth. According to groups of institutions, the greatest impact on lending to agriculture and silvi-culture has the Credit and Saving Associations (54\% of the total network portfolio). The agriculture is evaluated as one of the most potential sectors in the long term economy development and lending to this sector is strongly encouraged.

At the same time, there is room for an orientation of the microcredit portfolio to other important sectors, such as manufacturing or service industry collective, whose current weight is respectively 7.84 and 8.80 percent.

Compared to other countries in the region, the microcredit in Albania has potentials to expand.

During 2005 - 2013 the weighted average loan portfolio growth is low, compared to the same institutions in the region, affected by the rapid growth of this market in the region. The profitability indicators such as RoA and RoE for banks are calculated in positive values of $0.89 \%$ and $10.53 \%$ at the end of 2014 showing a noticeable improvement.

The main challenge of microfinance entities, beyond the banking institution remains the fund provisions for an ongoing activity. Providing this fund is vital because the capitalization of profits is not sufficient to handle cash flow, and owners capital increase is deemed as unnecessary by investors as long as it affects the shareholders increase in capital. Often funds are provided by international institutions and therefore they are in foreign currency. Institutions that accept funds in foreign currency face another challenge such as open foreign exchange positions.

As loans are provided in local currency (ALL), therefore microfinance institutions undertake other costs by using the hedging methods to exchange these funds. Therefore clients face higher costs. As a result of additional costs, the microfinance institution increase their rate of return.

In comparison with other microfinance markets, noted that Albanian customers pay higher interest rates. The highest price for the same client, although they know the market now directs the formalization of the latter to services cheaper in the financial sector.

\section{Conclusions}

$>$ The microfinance industry in Albania has had positive results and could therefore go toward commercialization process. On the other hand the increase in demand for financial services is immediately reflected, by licensing non-bank entities that provide electronic money transactions. These changes are showing self-regulation of non-bank entities to perform all service requiring full commercialization of this market

$>$ Data from the Bank of Albania database concluded that ROE in microfinance institutions in Albania has created deep fluctuations due to lack of strong supervision in this financial segment.

$>$ Transforming the microfinance institutions will affect the industry in the future to become self-sustaining, transparent and legally regulated. Participation of microfinance as a commercial bank, but not as a consumer financial requires primarily the consolidation of dedicated branches, also an understanding of the local culture, as well as making use of economies of scale and the training of specialists, and successful loan monitoring.

\section{Recommendations}

$>$ Microfinance institutions are in the restructuring process and therefore they should dare to undertake radical changes, and leaving behind the old way of doing business.

$>$ Bank of Albania should support more the microfinance sector, through easier policies. 
These policies can focus on: Lowering the dues that Microfinance institutions should pay during the first phase of commercialization.

$>$ On the other hand the government should adapt a full micro insurance fund (not partial as already is in place) and attach a full legal framework.

\section{References}

Bank Of Albania (Banka e Shqiperise) : www.bankofalbania.org

Daryl Collins, Jonathan Morduch, Stuart Rutherford dhe Orlanda Ruthven, (2009) "Portofolios of the poor: How the World's Poor Live on $\$ 2$ day", 2009

Grameen Bank. (April 12, 2009) A Short History of Grameen Bank. Retrieved April 23, 2009, from : www.grameeninfo.org lindex.php?option=com content\&task=view\&id=19\&ltemid=114

Microfinance, Commission Europeene, (2000) www.european-microfinance.org/

Nako A., Prifti J. (2011), "Microfinance in Albania", Bulletin of Bank of Albania, 2011

Robert P. Christen and Deborah Drake, (2002). "Commercialization: The New Reality of Microfinance", Botuar nga Deborah Drake

SALKO D (Co-author) 2004, "Rural Financial institutions and Albanian Reality", Monograph.

SALKO D, (Co-author) 2000 "Savings and Credit Association and their role in financing of rural sector" Bulletin of Agriculture Sciences, Number 2. September 2000

Stuart Rutherford dhe Sukhwinder Singh Arora (Mar 2010) "The Poor and Their Money: Microfinance From a Twenty-First Century Consumer's Perspective", Amazon publications 2010. 